\title{
Economics of Pea-Oat Intercropping System as Influenced by Integrated Nutrient Management
}

\author{
Khumlo Levish Chongloi ${ }^{1}$, K.K. Sharma ${ }^{2}$ and N. Khumdemo Ezung ${ }^{3} *$ \\ ${ }^{1}$ ACTO, KVK Chandel, ICAR Research Complex for NEH Region, Manipur Centre, \\ Lamphelpat, India \\ ${ }^{2}$ Assam Agricultural University, Jorhat-3, India \\ ${ }^{3}$ KVK, Kiphire, ICAR Research Complex for NEH Region, Nagaland Centre, Medziphema, \\ Nagaland-797106, India \\ *Corresponding author
}

\section{A B S T R A C T}

Keywords

Pea-oat, Economics, Integrated nutrient management, FYM, Vermicompost

Article Info

Accepted:

17 November 2019

Available Online:

10 December 2019
Field experiment on Economics of pea and oat intercropping system as influenced by integrated nutrient management (INM)was conducted during 2014-15 and 2015-16.Among the intercropping system the highest net return, economic efficiency, pea equivalent yield and GFEY was observed in 3:3 row proportions. INM on pea equivalent yield, GFEY, net return and economic efficiency were observed with addition of $50 \% \mathrm{~N}$ of RDF $+50 \%$ $\mathrm{N}$ through vermicompost, but the higher benefit-cost of 3.39 and 4.07 was observed in $50 \% \mathrm{~N}$ of RDF $+50 \% \mathrm{~N}$ through FYM, followed by $50 \% \mathrm{~N}$ of $\mathrm{RDF}+50 \% \mathrm{~N}$ through vermicompost, during the two years of experimentation, respectively.

\section{Introduction}

Food-forage-based systems provide a support to small and marginal farmers by adjusting a substantial part of their land exclusively for forage production in food crop based cropping systems. Forage needs to be integrated in the existing food based cropping system as crop intensification either in space or in time or both. Efficient crop sequence in intensive agriculture promotes productivity per unit area per unit time and provides more economic benefits to the farmers (Chandrika et al., 2013).

Intercropping is the agricultural practice of cultivating two or more crops at the same time and space, an old and commonly used cropping practice which aims to match efficiently crop demands to the available growth resources and labour. The most common advantage of intercropping is the 
production of greater yield on a given piece of land by making more efficient use of the available growth resources using a mixture of crops of different rooting characteristics, canopy structure, height, and nutrient requirements based on the complementary utilization of growth resources by the component crops. Moreover, intercropping improves soil fertility through biological nitrogen fixation with the use of legumes, increases soil conservation through greater ground cover than sole cropping, and provides better lodging resistance for crops susceptible to lodging than when grown in monoculture. Intercrops often reduce pest incidence and improve forage quality by increasing crude protein yield of forage. Intercropping of legume and non-legume forages is the best alternatives which ensures balanced nutrition and palatable fodder (Jeon et al., 1994) to the livestock and also help in fertilizer economy (Oleskho et al., 1995), advantageous in maintenance of soil fertility, efficient land utilization and above all economizing the concentrate feeding.

However, meager information is available on the effect of organic and inorganic source of nutrition on pea-oat. Therefore, an attempt was made to evaluate different organic and inorganic sources of nutrition for realizing higher yield and economics in oat-pea intercropping.

\section{Materials and Methods}

The present investigation was carried out in the sandy loam soil of the Instructional-Cum Research (ICR) Farm of Assam Agricultural University, Jorhat, located at $26^{0} 45^{\prime} \mathrm{N}$ latitude and $94^{\circ} 12^{\prime}$ E longitudes at an elevation of about $87 \mathrm{~m}$ above mean sea level. The soil was medium in organic carbon $(0.52$ and $0.53 \%$ ) content, low in available nitrogen (207.50 and $213.47 \mathrm{~kg} / \mathrm{ha}$ ) and medium in available phosphorus (22.52 and $23.12 \mathrm{~kg} / \mathrm{ha}$ ), potassium (145.31 and $148.71 \mathrm{~kg} / \mathrm{ha})$, DTPA$\mathrm{Zn}(1.25$ and $1.26 \mathrm{mg} / \mathrm{kg})$ and DTPA-Fe (116.33 and $120.51 \mathrm{mg} / \mathrm{kg}$ ) with acidic ( $\mathrm{pH}$ in 5.2 and 5.4) in reaction having 1.29 and 1.27 $\mathrm{Mg} / \mathrm{m}^{3}$ bulk density, Mean weight diameter 0.54 and $0.57 \mathrm{~mm}$ and biomass carbon 150.42 and $158.37 \mu \mathrm{g} \mathrm{g}^{-1}$. The experiment was laid out in split plot design with three replications for two years. There were four main plot treatments comprising of sole crop oat, sole crop pea, different row proportion of oat and pea i.e. 3:2 and 3:3 along with four combinations of nutrient management viz. RDF (inorganic), $50 \% \mathrm{~N}$ of RDF $+50 \% \mathrm{~N}$ through FYM, $50 \% \mathrm{~N}$ of RDF $+50 \% \mathrm{~N}$ through vermicompost and 50\% $\mathrm{N}$ through FYM $+50 \% \mathrm{~N}$ through vermicompost were superimposed on each of the main plots as subplot treatments. The seeds of oat were treated with PSB and pea seeds were treated with PSB and Rhizobium culture @ 100g/kg seeds for all the treatment combinations before sowing of seeds.

\section{Results and Discussion}

\section{Productivity and economics}

\section{Intercropping systems}

The data from the two years experiment revealed that the pea equivalent yield and green forage equivalent yield of the system as a whole (Table 1) were significantly superior in sole pea, however among the different intercropping systems the highest pea equivalent yield (767.45 and 878.41 q/ha) and green forage equivalent yield (1151.18 and $1317.62 \mathrm{q} / \mathrm{ha}$ ) of the system were observed in 3:3 oat+pea intercropping over sole oats during 2014-15 and 2015-16, respectively. Similar observations were also reported by Tiwana et al., (2008).

The land equivalent ratio (LER) gives accurate assessment of biological efficiency of the 
intercropping situations. In the present study the highest LER values were observed under 3:3 row proportions of oat+pea intercropping recording 1.10 and 1.09 in two successive years indicating 10and 9 percent advantage with the varying magnitudes depending upon row proportions. It might be attributed to the development of the better complementary relationship, leading to better use of growth resources. The result confirms the findings of Devi, et al., 2014. The higher LER values were also recorded in 3:2 ratios of pea+oat intercropping over sole cropping in both the years of experimentation which indicates the yield advantage over sole cropping. The results are in close conformity with the findings of Jannoura et al., (2013). The mixtures out yielded the pure sowings (LER $>1)$. Therefore, this means that a mixture uses environmental resources better than pure sowing and competition between mixture components is not high (Albayrak et al., 2004) (Table 2).

As far as the relative crowding coefficient is concerned it was recorded that the expected yield of oats was lower, as the coefficient were less than 1 , whereas the pea gave more yield than expected under $3: 3$ row proportions but in 3:2 row proportions of pea+oat the expected yield was low. It was also revealed that the relative crowding coefficient of the pea was greater than 1 , in 3:3 row ratio indicating yield advantage compared with their monoculture due to mutual cooperation. Higher value of RCC for oats was obtained from 3:3.

Aggressivity indicates the simple difference between dominant and dominated component crops. Data on aggressivity (Table 3) showed that the values were found to be negative for pea in 3:2 row proportions indicating the dominance of oats over pea in both the experimental years. In 3:3 row proportions of pea+oat intercropping the positive values were recorded showing the dominance of pea over oats in both the years.

Computed competitive ratio showed that, pea in 3:3 ratio of pea+oat intercropping system had higher competitive ability over 3:2 ratio of pea+oat intercropping system in both the years of experimentation.

The highest value 1.05 and 1.01 in 2014-15 and 2015-16, respectively reflects its better performance. On the other hand, the least value of competitive ratio in case of oats in the ratio of 3:3 intercropping system indicated that the competitive ability of oats over pea under this system was lower than 3:2 row proportions of pea+oat in both the years.

The gross return as influenced by intercropping was found to be significant. The highest gross return was observed in sole pea during the two years of experimentation. Among the intercropping systems 3:3 ratio gave the highest gross return being 76745.41 and 87841.34 during 2014-15 and 2015-16, respectively

The data on the highest net return of '89827.46 and ' 111619.47 was recorded in C2 (sole cropping) during the two successive years. Among the intercropping system the significantly higher net return was observed in C4 (3:3 row proportions of pea+oat) being 45510.89 and 56606.81 in both the years.

Economic efficiency as influence by intercropping was found to be significant in both the years of experimentation. The highest economic efficiency was observed in sole pea culture with the value of $1122.84 / \mathrm{day} / \mathrm{ha}$ and 1395.24/day/ha during 2014-15 and 2015-16 respectively.

Among the intercropping systems the highest value of 568.89/day/ha and 707.59/day/ha was recorded in 3:3 row proportions of oat-pea 
intercropping during 2014-15 and 2015-16, respectively. The lowest economic efficiency was observed in sole oat culture in both the years of experimentations.

\section{Integrated nutrient management}

Pea equivalent yield and green forage equivalent yield of the system as a whole influenced significantly by the different nutrient management (Table 1), application of $50 \% \mathrm{~N}$ through vermicompost $+50 \% \mathrm{~N}$ through inorganic fertilizer gave significantly higher Pea equivalent yield and green forage equivalent yield showing increased in yield over addition of only organic fertilizers i.e.
$50 \% \mathrm{~N}$ through vermicompost $+50 \% \mathrm{~N}$ through FYM during 2014-15 and 2015-16, respectively which was followed by addition of $50 \% \mathrm{~N}$ through FYM $+50 \% \mathrm{~N}$ through inorganic fertilizer in both the years of experimentation.

Relative Crowding Coefficient was not influenced significantly by the different nutrient management in both the years and the expected yield was also found to be lower, however in pea though there was no significant difference the expected yield due to different integrated nutrient management was higher as the coefficient were higher than 1 in both the years of experimentation.

Table.1 Green forage yield, Dry matter yield of pea and pea equivalent yield as influence by intercropping and INM

\begin{tabular}{|c|c|c|c|c|}
\hline \multirow[t]{2}{*}{ Treatments } & \multicolumn{2}{|c|}{$\begin{array}{l}\text { Pea equivalent yield } \\
\text { (q/ha) }\end{array}$} & \multicolumn{2}{|c|}{ GFEY (q/ha) } \\
\hline & 2014-15 & 2015-16 & 2014-15 & 2015-16 \\
\hline $\mathrm{C}_{1}$ oat sole & 357.11 & 382.35 & 538.16 & 573.52 \\
\hline $\mathrm{C}_{2}$ pea sole & 1240.65 & 1458.57 & 1860.98 & 2187.86 \\
\hline$C_{3}$ oat+pea $(3: 2)$ & 649.70 & 743.73 & 974.55 & 1115.59 \\
\hline$C_{4}$ oat+pea (3:3) & 767.45 & 878.41 & 1151.18 & 1317.62 \\
\hline SEm \pm & 12.92 & 11.80 & 22.20 & 26.17 \\
\hline $\mathrm{CD}(\mathrm{P}=\mathbf{0 . 0 5})$ & 39.11 & 35.71 & 67.19 & 79.20 \\
\hline \multicolumn{5}{|c|}{ Integrated nutrient management $(\mathbf{F})$} \\
\hline F $_{1}$ RDF (inorganic) & 672.45 & 776.55 & 1008.67 & 1164.83 \\
\hline$F_{2} 50 \% \mathrm{~N}$ of $\mathrm{RDF}+50 \% \mathrm{~N}$ through $\mathrm{FYM}$ & 813.90 & 930.10 & 1220.85 & 1395.14 \\
\hline $\begin{array}{c}\mathrm{F}_{3} \mathbf{5 0 \%} \mathrm{N} \text { of } \mathbf{R D F}+\mathbf{5 0 \%} \mathrm{N} \text { through } \\
\text { vermicompost }\end{array}$ & 881.32 & 1003.99 & 1324.49 & 1505.98 \\
\hline $\begin{array}{c}F_{4} 100 \% \text { organic }(50 \% \mathrm{~N} \text { through } \\
\text { FYM+50\% } \mathrm{N} \text { through vermicompost }\end{array}$ & 647.25 & 752.43 & 970.87 & 1128.64 \\
\hline SEm \pm & 12.52 & 12.86 & 18.13 & 23.60 \\
\hline $\mathrm{CD}(\mathrm{P}=\mathbf{0 . 0 5})$ & 37.91 & 38.92 & 54.87 & 71.44 \\
\hline \multicolumn{5}{|c|}{ Interaction $(\mathrm{CxF})$} \\
\hline SEm \pm & 21.69 & 22.27 & 31.40 & 40.89 \\
\hline $\mathrm{CD}(\mathrm{P}=\mathbf{0 . 0 5})$ & 65.66 & 67.41 & 95.04 & 123.75 \\
\hline CV $(\%)$ & 4.45 & 3.54 & 5.09 & 5.23 \\
\hline
\end{tabular}


Table.2 Land equivalent ratio (LER) and Relative crowding coefficient as influenced by cropping systems and INM

\begin{tabular}{|c|c|c|c|c|c|c|}
\hline Treatments & \multicolumn{2}{|c|}{ LER } & \multicolumn{4}{|c|}{$\mathbf{R C C}$} \\
\hline & \multirow[b]{2}{*}{ 2014-15 } & \multirow[b]{2}{*}{ 2015-16 } & \multicolumn{2}{|c|}{ 2014-15 } & \multicolumn{2}{|c|}{ 2015-16 } \\
\hline Intercropping (C) & & & Oats & Pea & Oats & Pea \\
\hline $\mathrm{C}_{1}$ oat sole & 1.00 & 1.00 & 1.00 & 1.00 & 1.00 & 1.00 \\
\hline $\mathrm{C}_{2}$ pea sole & 1.00 & 1.00 & 1.00 & 1.00 & 1.00 & 1.00 \\
\hline $\mathrm{C}_{3}$ oat+pea $(3: 2)$ & 1.09 & 1.08 & 0.85 & 0.75 & 0.89 & 0.70 \\
\hline $\mathrm{C}_{4}$ oat+pea $(3: 3)$ & 1.10 & 1.09 & 0.94 & 1.64 & 0.96 & 1.54 \\
\hline SEm \pm & 1.01 & 0.01 & 0.02 & 0.03 & 0.02 & 0.03 \\
\hline $\mathrm{CD}(\mathrm{P}=0.05)$ & 0.05 & 0.04 & 0.08 & 0.09 & 0.06 & 0.12 \\
\hline \multicolumn{7}{|c|}{ Integrated nutrient management $(\mathrm{F})$} \\
\hline$F_{1}$ RDF (inorganic) & 1.05 & 1.04 & 0.94 & 1.10 & 0.95 & 1.06 \\
\hline $\begin{array}{c}\mathrm{F}_{2} \mathbf{5 0 \%} \mathrm{N} \text { of } \mathrm{RDF}+\mathbf{5 0 \%} \mathrm{N} \text { through } \\
\text { FYM }\end{array}$ & 1.03 & 1.04 & 0.93 & 1.05 & 0.96 & 1.04 \\
\hline $\begin{array}{c}\mathrm{F}_{3} \mathbf{5 0 \%} \mathrm{N} \text { of } \mathrm{RDF}+50 \% \mathrm{~N} \text { through } \\
\text { vermicompost }\end{array}$ & 1.05 & 1.04 & 0.96 & 1.11 & 0.96 & 1.04 \\
\hline $\begin{array}{l}\mathrm{F}_{4} \mathbf{1 0 0 \%} \text { organic }(50 \% \mathrm{~N} \text { through } \\
\text { FYM+50\% } \mathrm{N} \text { through vermicompost }\end{array}$ & 1.05 & 1.05 & 0.95 & 1.12 & 0.97 & 1.09 \\
\hline SEm \pm & 0.01 & 0.01 & 0.01 & 0.02 & 0.017 & 0.04 \\
\hline $\mathrm{CD}(\mathrm{P}=\mathbf{0 . 0 5})$ & NS & NS & NS & NS & NS & NS \\
\hline \multicolumn{7}{|c|}{ Interaction $(\mathrm{CxF})$} \\
\hline SEm \pm & 0.02 & 0.02 & 0.03 & 0.05 & 0.03 & 0.07 \\
\hline $\mathrm{CD}(\mathrm{P}=\mathbf{0 . 0 5})$ & NS & NS & NS & NS & NS & NS \\
\hline CV (\%) & 4.64 & 3.82 & 7.70 & 7.20 & 5.83 & 9.74 \\
\hline
\end{tabular}

Table.3 Aggressivity and competitive ratio as influenced by cropping systems and INM

\begin{tabular}{|c|c|c|c|c|c|c|c|c|}
\hline \multirow{3}{*}{ Treatments } & \multicolumn{4}{|c|}{ Aggressivity } & \multicolumn{4}{|c|}{ Competitive ratio } \\
\hline & \multicolumn{2}{|c|}{ 2014-15 } & \multicolumn{2}{|c|}{ 2015-16 } & \multicolumn{2}{|c|}{ 2014-15 } & \multicolumn{2}{|c|}{ 2015-16 } \\
\hline & Oats & Pea & Oats & Pea & Oats & Pea & Oats & Pea \\
\hline \multicolumn{9}{|c|}{ Cropping system $(\mathbf{C})$} \\
\hline$C_{1}$ oat sole & - & - & - & - & - & - & - & - \\
\hline $\mathrm{C}_{2}$ pea sole & - & - & - & - & - & - & - & - \\
\hline$C_{3}$ oat+pea $(3: 2)$ & 0.03 & -0.03 & 0.004 & -0.004 & 1.03 & 0.97 & 1.01 & 0.99 \\
\hline$C_{4}$ oat+pea $(3: 3)$ & -0.04 & 0.04 & -0.008 & 0.008 & 0.96 & 1.05 & 0.99 & 1.01 \\
\hline \multicolumn{9}{|c|}{ Integrated nutrient management $(\mathbf{F})$} \\
\hline F $_{1}$ RDF (inorganic) & -0.017 & 0.017 & -0.016 & 0.016 & 0.97 & 1.03 & 0.98 & 1.03 \\
\hline $\begin{array}{c}\mathrm{F}_{2} \mathbf{5 0 \%} \mathrm{N} \text { of } \mathrm{RDF}+50 \% \mathrm{~N} \\
\text { through } \mathrm{FYM}\end{array}$ & -0.008 & 0.008 & -0.009 & 0.009 & 0.99 & 1.01 & 0.99 & 1.02 \\
\hline $\begin{array}{c}F_{3} 50 \% \mathrm{~N} \text { of } \mathrm{RDF}+50 \% \mathrm{~N} \\
\text { through vermicompost }\end{array}$ & -0.008 & 0.008 & 0.001 & -0.001 & 0.99 & 1.01 & 1.00 & 0.99 \\
\hline $\begin{array}{c}\mathrm{F}_{4} 100 \% \text { organic }(50 \% \mathrm{~N} \\
\text { through FYM+50\% } \mathrm{N} \\
\text { through vermicompost }\end{array}$ & 0.015 & -0.015 & 0.019 & -0.019 & 1.03 & 0.98 & 1.03 & 0.97 \\
\hline
\end{tabular}


Table.4 Gross return, net return and economic efficiency as influenced by cropping systems and INM

\begin{tabular}{|c|c|c|c|c|c|c|}
\hline \multirow[t]{2}{*}{ Treatments } & \multicolumn{2}{|c|}{ Gross return (Rs.) } & \multicolumn{2}{|c|}{ Net return (Rs.) } & \multicolumn{2}{|c|}{$\begin{array}{l}\text { Economic efficiency } \\
\text { (Rs /day/ha) }\end{array}$} \\
\hline & 2014-15 & 2015-16 & 2014-15 & 2015-16 & 2014-15 & 2015-16 \\
\hline \multicolumn{7}{|c|}{ Cropping system (C) } \\
\hline$C_{1}$ oat sole & 35660.87 & 38234.67 & 7902.56 & 10426.40 & 98.78 & 130.33 \\
\hline$C_{2}$ pea sole & 124065.35 & 145857.36 & 89827.46 & 111619.47 & 1122.84 & 1395.24 \\
\hline$C_{3}$ oat+pea $(3: 2)$ & 64969.80 & 74372.78 & 34096.28 & 43499.25 & 426.20 & 543.74 \\
\hline$C_{4}$ oat+pea $(3: 3)$ & 76745.41 & 87841.34 & 45510.89 & 56606.81 & 568.89 & 707.59 \\
\hline SEm \pm & 1244.64 & 1471.60 & 843.32 & 1471.60 & 10.54 & 18.39 \\
\hline $\mathrm{CD}(\mathrm{P}=\mathbf{0 . 0 5})$ & 3766.82 & 4453.69 & 2552.26 & 4453.69 & 31.90 & 55.67 \\
\hline \multicolumn{7}{|c|}{ Integrated nutrient management $(\mathbf{F})$} \\
\hline F $_{1}$ RDF (inorganic) & 67194.78 & 77655.20 & 40844.39 & 51254.82 & 510.55 & 640.69 \\
\hline $\begin{array}{c}\mathrm{F}_{2} \mathbf{5 0 \%} \mathrm{N} \text { of RDF }+50 \% \\
\mathrm{~N} \text { through FYM }\end{array}$ & 81389.70 & 93009.64 & 53351.50 & 64971.44 & 667.00 & 812.14 \\
\hline $\begin{array}{l}\mathrm{F}_{3} \mathbf{5 0 \%} \mathrm{N} \text { of } \mathrm{RDF}+\mathbf{5 0 \%} \\
\mathrm{N} \text { through vermicompost }\end{array}$ & 88132.43 & 100398.56 & 54094.23 & 66360.35 & 676.18 & 829.50 \\
\hline $\begin{array}{c}\mathrm{F}_{4} 100 \% \text { organic }(50 \% \mathrm{~N} \\
\text { through } \mathrm{FYM}+50 \% \mathrm{~N} \\
\text { through vermicompost }\end{array}$ & 64724.41 & 75242.75 & 29047.09 & 39565.32 & 363.09 & 494.57 \\
\hline SEm \pm & 1252.65 & 1244.30 & 927.78 & 1244.30 & 11.59 & 15.55 \\
\hline $\mathrm{CD}(\mathrm{P}=\mathbf{0 . 0 5})$ & 3791.07 & 3765.79 & 2807.86 & 3765.79 & 35.09 & 47.07 \\
\hline \multicolumn{7}{|c|}{ Interaction $(\mathbf{C x F})$} \\
\hline SEm \pm & 2169.67 & 2155.20 & 1606.96 & 2155.20 & 20.08 & 26.94 \\
\hline $\mathrm{CD}(\mathbf{P}=\mathbf{0 . 0 5})$ & 6566.32 & 6522.54 & 4863.35 & 3765.79 & 60.79 & 81.53 \\
\hline CV (\%) & 4.29 & 4.41 & 4.94 & 6.88 & 4.94 & 6.88 \\
\hline
\end{tabular}

Table.5 Economics indices as influenced by cropping systems and INM

\begin{tabular}{|c|c|c|c|}
\hline \multirow{2}{*}{\multicolumn{2}{|c|}{ Treatments }} & \multicolumn{2}{|c|}{ Benefit -cost ratio } \\
\hline & & 2014-15 & 2015-16 \\
\hline $\mathbf{C}_{1} \mathbf{F}_{1}$ & Sole oat + RDF (inorganic) & 0.48 & 0.59 \\
\hline $\mathbf{C}_{1} \mathbf{F}_{2}$ & Sole oat $+50 \% \mathrm{~N}$ of RDF $+50 \% \mathrm{~N}$ through FYM & 0.47 & 0.57 \\
\hline $\mathbf{C}_{1} \mathbf{F}_{3}$ & Sole oat $+50 \% \mathrm{~N}$ of $\mathrm{RDF}+50 \% \mathrm{~N}$ through vermicompost & 0.25 & 0.33 \\
\hline $\mathbf{C}_{1} \mathbf{F}_{4}$ & Sole oat $+50 \% \mathrm{~N}$ through FYM $+50 \% \mathrm{~N}$ through vermicompost & 0.04 & 0.11 \\
\hline $\mathbf{C}_{2} \mathbf{F}_{1}$ & Sole pea + RDF (inorganic) & 2.71 & 3.39 \\
\hline $\mathbf{C}_{2} \mathbf{F}_{2}$ & Sole pea $+50 \% \mathrm{~N}$ of RDF $+50 \% \mathrm{~N}$ through FYM & 3.39 & 4.07 \\
\hline $\mathbf{C}_{2} \mathbf{F}_{3}$ & Sole pea $+50 \% \mathrm{~N}$ of RDF $+50 \% \mathrm{~N}$ through vermicompost & 2.93 & 3.61 \\
\hline $\mathbf{C}_{2} \mathbf{F}_{4}$ & Sole pea $+50 \% \mathrm{~N}$ through $\mathrm{FYM}+50 \% \mathrm{~N}$ through vermicompost & 1.66 & 2.17 \\
\hline $\mathbf{C}_{3} \mathbf{F}_{1}$ & Oat + pea - 3:2 $\quad(60 / 40)+\mathrm{RDF}$ (inorganic) & 1.19 & 1.52 \\
\hline $\mathbf{C}_{3} \mathbf{F}_{2}$ & Oat + pea $-3: 2(60 / 40)+50 \% \mathrm{~N}$ of RDF $+50 \% \mathrm{~N}$ through FYM & 1.48 & 1.87 \\
\hline $\mathbf{C}_{3} \mathbf{F}_{3}$ & Oat +pea $-3: 2(60 / 40)+50 \% \mathrm{~N}$ of RDF $+50 \% \mathrm{~N}$ through vermicompost & 1.26 & 1.55 \\
\hline $\mathbf{C}_{3} \mathbf{F}_{4}$ & Oat + pea $-3: 2(60 / 40)+50 \% \mathrm{~N}$ through FYM $+50 \% \mathrm{~N}$ through vermicompost & 0.59 & 0.82 \\
\hline $\mathbf{C}_{4} \mathbf{F}_{1}$ & Oat + pea $-3: 3(50 / 50)+$ RDF (inorganic) & 1.55 & 1.93 \\
\hline $\mathbf{C}_{4} \mathbf{F}_{2}$ & Oat + pea $-3: 3(50 / 50)+50 \% \mathrm{~N}$ of RDF $+50 \% \mathrm{~N}$ through FYM & 1.93 & 2.34 \\
\hline $\mathbf{C}_{4} \mathbf{F}_{3}$ & Oat + pea $-3: 3(50 / 50)+50 \% \mathrm{~N}$ of $\mathrm{RDF}+50 \% \mathrm{~N}$ through vermicompost & 1.66 & 1.99 \\
\hline $\mathbf{C}_{4} \mathbf{F}_{4}$ & Oat + pea $-3: 3(50 / 50)+50 \% \mathrm{~N}$ through FYM $+50 \% \mathrm{~N}$ through vermicompost & 0.82 & 1.13 \\
\hline
\end{tabular}


Aggressivity due to integrated nutrient management showed that pea has dominated over oats in the treatment combinations of $\mathrm{F}_{1}$ (100\% RDF), $\mathrm{F}_{2}(50 \% \mathrm{~N}$ through FYM $+50 \%$ $\mathrm{N}$ through inorganic fertilizers) and $\mathrm{F}_{3}(50 \% \mathrm{~N}$ through vermicompost $+50 \% \mathrm{~N}$ through inorganic fertilizers) however, in $\mathrm{F}_{4}$ oats dominates over pea in both the years of experimentation. Competitive ratio due to integrated nutrient management shows that oats was more competitive in $\mathrm{F}_{4}(50 \% \mathrm{~N}$ through vermicompost $+50 \% \mathrm{~N}$ through FYM) and pea in $F_{1}(100 \%$ RDF) during the years of experimentation.

Effect of integrated nutrient management on gross return was found to be significantly higher in $\mathrm{F}_{3}(50 \% \mathrm{~N}$ through vermicompost + $50 \% \mathrm{~N}$ through inorganic fertilizers) which was followed by $\mathrm{F}_{2}(50 \% \mathrm{~N}$ through $\mathrm{FYM}+$ $50 \% \mathrm{~N}$ through inorganic fertilizers) during 2014-15 and 2015-16.

The integrated nutrient management of $50 \% \mathrm{~N}$ through vermicompost $+50 \% \mathrm{~N}$ through inorganic fertilizer) gave significantly higher net return of `54094.23 and `66360.35 over other treatment combinations during 2014-15 and 2015-16, respectively over all other treatment combinations in both the years of experimentation.

The economics of pea + oat base intercropping and integrated nutrient management resulted that the highest net return was obtained from sole pea with the nutrient management of $50 \%$ $\mathrm{N}$ through vermicompost+ $50 \% \mathrm{~N}$ through inorganic fertilizers $\left(\mathrm{F}_{3}\right)$ which was followed by $\mathrm{F}_{2}(50 \% \mathrm{~N}$ through $\mathrm{FYM}+50 \% \mathrm{~N}$ through inorganic fertilizers. A similar finding was also reported by Devi et al., (2014).

Integrated nutrient management on economic efficiency was found to be significant during the two years of experimentations (Table 4).
The highest economic efficiency of 676.18/day/ha and 829.50/day/ha was recorded in the treatment combinations of 50 $\% \mathrm{~N}$ through vermicompost $+50 \% \mathrm{~N}$ through inorganic fertilizer which was followed by $50 \% \mathrm{~N}$ through $\mathrm{FYM}+50 \% \mathrm{~N}$ through inorganic fertilizer during 2014-15 and 201516, respectively. The findings are in corroboration with Kumar et al., 2014. The highest benefit-cost ratio as revealed in Table 5 was obtained from $\mathrm{C}_{2} \mathrm{~F}_{2}$ (sole cropping with nutrient management of $50 \% \mathrm{~N}$ through FYM $+50 \% \mathrm{~N}$ through inorganic fertilizer) showing the value of 3.39 and 4.07 during the two years of experimentations which was followed by $\mathrm{C}_{2} \mathrm{~F}_{3}$ (sole pea with $50 \% \mathrm{~N}$ through vermicompost $+50 \% \mathrm{~N}$ through inorganic fertilizer).

Among the intercropping system the highest benefit-cost ratio was observed in $\mathrm{C}_{4} \mathrm{~F}_{2}$ (3:3 row proportions + application of nutrients with $50 \% \mathrm{~N}$ through $\mathrm{FYM}+50 \% \mathrm{~N}$ through inorganic fertilizer which was followed by $\mathrm{C}_{4} \mathrm{~F}_{3}$ (3:3 row proportions + application of nutrients with $50 \% \mathrm{~N}$ through vermicompost + $50 \% \mathrm{~N}$ through inorganic fertilizer during 2014-15 and 2015-16, experiment.

Though the gross return was recorded to be highest in $\mathrm{C}_{2} \mathrm{~F}_{3}$ (sole pea with application of $50 \% \mathrm{~N}$ through vermicompost $+50 \% \mathrm{~N}$ through inorganic fertilizers) but the higher benefit cost ratio was computed from $\mathrm{C}_{2} \mathrm{~F}_{2}$ (sole pea with $50 \% \mathrm{~N}$ through $\mathrm{FYM}+50 \% \mathrm{~N}$ through inorganic fertilizers) which might be due to higher cost of production i.e. high cost of vermicompost. Based on the two year experimentation, it can be concluded that, in the rice-fallow systems, introduction of foodforage intercropping systems having component crop of pea and oat with planting geometry of 3:3 row proportion having considerable positive effect on the yield performance and addition of vermicompost can saved $50 \%$ of inorganic fertilizers. 


\section{References}

Albayrak et al., (2004). Effects of seed rates on forage production and hay quality of vetch-triticale mixtures. Asian $J$. Plant Sci. 3(6): 752-756.

Chandreka et al., (2013). Production potential and economic viability of food forage based cropping systems in southern Telangana region of Andhra Pradesh. J.Res. ANGRAU 41(3): 47-52.

Devi et al., (2014). Effect of nitrogen levels, organic manures and azotobacter inoculation on yield economics of multi-cut oats. Forage Res. 40(1): 3643.

Gomez, K.A. and A.A. Gomez, 1984. Statistical procedure for agricultural research. Wiily Interscience Publication, John Willy and sons, New York.

Jannoura et al., (2013). Organic fertilizer effects on pea yield, nutrient uptake, microbial root colonization and soil microbial biomass indices in organic farming systems. Europ. J. Agron.49: $32-41$.

Jeon et al., (1994). Effects of intercropping methods of sorghum $X$ sudan grass hybrid with legumes and $\mathrm{N}$ levels on palatability for ruminants. Korean $J$. Anim. Sci. 36: 323.

Kumar et al., (2014). Integrated Nutrient Management in Rice-Pea Cropping System for Sustainable Productivity. Int. J. Engg. Res. Technol.3(4).

Oleshko et al., (1995). A source of supplementary fodder. Kormoproizvodstvo 3: 23.

Tiwana et al., (2008). Fodder productivity, quality and seed yield of multicut oat grown pure and in mixture with different seed rates of sarson. Forage Res. 33(4): 224-226.

\section{How to cite this article:}

Khumlo Levish Chongloi, K. K. Sharma and Khumdemo Ezung, N. 2019. Economics of PeaOat Intercropping System as Influenced by Integrated Nutrient Management. Int.J.Curr.Microbiol.App.Sci. 8(12): 2176-2183. doi: https://doi.org/10.20546/ijcmas.2019.812.258 